\title{
Papers
}

\section{A systematic review of the effects of screening for colorectal cancer using the faecal occult blood test, Hemoccult}

\author{
Bernie Towler, Les Irwig, Paul Glasziou, Jan Kewenter, David Weller, Chris Silagy
}

\begin{abstract}
Objective: To review effectiveness of screening for colorectal cancer with faecal occult blood test, Hemoccult, and to consider benefits and harms of screening.

Design: Systematic review of trials of Hemoccult screening, with meta-analysis of results from the randomised controlled trials.
\end{abstract}

Subjects: Four randomised controlled trials and two non-randomised trials of about 330000 and 113000 people respectively aged $\geqslant 40$ years in five countries. Main outcome measures: Meta-analysis of effects of screening on mortality from colorectal cancer.

Results: Quality of trial design was generally high, and screening resulted in a favourable shift in the stage distribution of colorectal cancers in the screening groups. Meta-analysis of mortality results from the four randomised controlled trials showed that those allocated to screening had a reduction in mortality from colorectal cancer of $16 \%$ (relative risk 0.84 (95\% confidence interval 0.77 to 0.93$)$ ). When adjusted for attendance for screening, this reduction was $23 \%$ (relative risk 0.77 (0.57 to 0.89$)$ ) for people actually screened. If a biennial Hemoccult screening programme were offered to 10000 people and about two thirds attended for at least one Hemoccult test, 8.5 (3.6 to 13.5) deaths from colorectal cancer would be prevented over a period of 10 years.

Conclusion: Although benefits of screening are likely to outweigh harms for populations at high risk of colorectal cancer, more information is needed about the harmful effects of screening, the community's responses to screening, and costs of screening for different healthcare systems before widespread screening can be recommended.

\section{Introduction}

Colorectal cancer is a leading cause of illness and death in the Western world. In Australia, the United Kingdom, and the United States it is the commonest cancer in women after breast cancer (age standardised incidence 22-33 per 100000 ) and in men after prostate and lung cancer (age standardised incidence 31-47 per 100000$). .^{12}$ Just under half of all people affected will die from their disease. ${ }^{12}$ The human and financial costs of this disease have prompted considerable research efforts to evaluate the ability of screening tests to detect the cancer at an early, curable stage. Tests that have been considered for screening include faecal occult blood tests, sigmoidoscopy, and colonoscopy.

We have reviewed the evidence about the ability of screening with the faecal occult blood test Hemoccult to reduce mortality from colorectal cancer. Since follow up in Hemoccult screening trials has not been sufficiently long to clarify the effect of detecting and removing adenomas on mortality, our results reflect the effect of detecting early colorectal cancer on mortality. As well as evaluating the effectiveness of screening, we also considered its benefits and harms. If screening is effective, for which populations would screening be likely to be of net benefit, given the potential harms? Weighing the benefits and harms of screening helps to define health policy and future research needs. We reviewed the information from the screening trials about physical harm associated with follow up colonoscopy or sigmoidoscopy. Other harmful screening effects include disruption to lifestyle, the stress and discomfort of testing and further investigations, and the anxiety caused by false positive tests. ${ }^{3}$ This review will also be published and maintained on The Cochrane Library, an electronic publication of the Cochrane Collaboration (Oxford: Update Software).

\section{Methods}

We conducted a comprehensive search of the health literature for all controlled trials of screening for colorectal cancer by means of faecal occult blood tests. The search included correspondence with trialists for unpublished data and clarification of published results. Details of this search are available on request. The trials were independently assessed for their quality by BT and PG using criteria recommended by the Cochrane Collaboration. ${ }^{4}$ Disagreements about quality were resolved by discussion.

Data from the trials were independently extracted by BT and LI and analysed using Meta-analyst version $0.991 .^{5}$ We performed the data analysis on an "intention to screen" basis-using the groups that subjects were randomised to whether or not they were ever screened. To determine the size of the effect of screening on mortality from colorectal cancer, we estimated relative risks and risk differences, firstly for each trial and then overall, using fixed and random effects models and then used the $\chi^{2}$ test for heterogeneity of effects. ${ }^{56}$

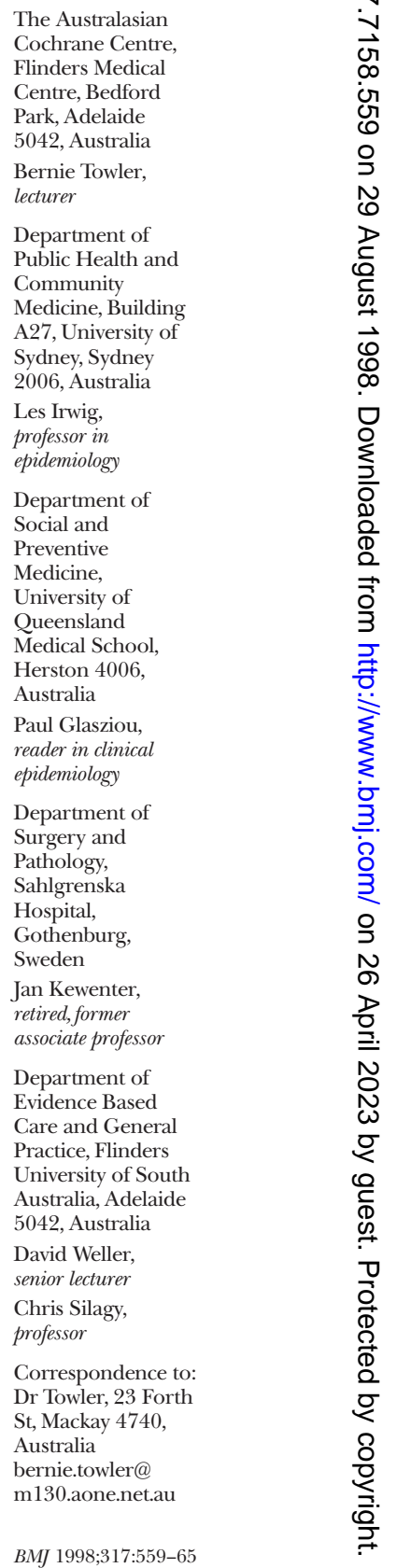


Analysis by intention to screen underestimates the effect that would be seen in those who actually attended screening. Hence, as a secondary analysis, we adjusted for attendance for screening in individual trials using a previously published method. ${ }^{7}$ Essentially, this involves dividing the intention to screen effect (relative risk reduction) by the proportion attending.

\section{Results}

\section{Trial characteristics}

We identified four randomised controlled trials ${ }^{8-11}$ and two non-randomised controlled trials ${ }^{12}{ }^{13}$ that evaluated the effectiveness of screening with the faecal occult blood test Hemoccult. The randomised trials involved about 330000 people in Denmark, England, Sweden, and the United States, and the nonrandomised trials involved about 113000 people in France and the United States. Table 1 shows the characteristics of the trials. Most trials commenced in the mid-1970s or early 1980s and involve annual or biennial Hemoccult screening. ${ }^{8-11}$ The nonrandomised New York trial evaluated Hemoccult in addition to sigmoidoscopy, which was offered to all trial participants. ${ }^{12}$

The Funen, Nottingham, and Gothenburg trials randomly allocated individuals or households identified from general practitioner records or population registers to invitation to screening with Hemoccult or to control groups (table 2). The Minnesota and New York trials allocated people who had agreed to participate in the trials ("volunteers") to screening or control groups, while the Burgundy trial, which started in 1988, non-randomly allocated groups from defined areas to screening or control groups (table 2). The number of groups allocated was not reported. The age of participants varied from trial to trial, with all being at least 40 years old (table 1). Follow up continues in at least four of the trials (table 1).
In all six trials participants were encouraged to restrict their diet or medications around the time of the Hemoccult tests in order to reduce the possibility of a false positive result. The nature of these restrictions varied from trial to trial. For most trials, the Hemoccult stool slides were not rehydrated, resulting in a low test positivity rate $(0.8 \%-2.4 \%)$ and a higher positive predictive value for colorectal cancer (5.6\%-17.7\%) compared with the rehydrated test, for which the test positivity rate was $4.8 \%-9.8 \%$ and the positive predictive value was $2.2 \%-4.2 \%$ (table 1 ).

In all the trials, those subjects with a positive Hemoccult test were referred for further investigation, mainly colonoscopy or sigmoidoscopy with double contrast barium enema. Colorectal neoplasms (cancers and adenomas) found on further investigation were removed. In the Minnesota trial 38\% of the group offered annual screening and $28 \%$ of the group offered biennial screening had at least one colonoscopy. ${ }^{8}$ Some $2 \%-3 \%$ of the screening group in the Nottingham and Funen trials ${ }^{9}{ }^{10}$ and about $6 \%$ in the Gothenburg trial ${ }^{14}$ had at least one endoscopy (colonoscopy or sigmoidoscopy). About 4\% of the screening group in the New York study were investigated for a positive Hemoccult test, most of these having colonoscopy. ${ }^{12}$

\section{Trial design quality}

Randomisation was performed appropriately for four of the trials, resulting in comparable study groups (table 2). ${ }^{8-1115}$ The New York study was nonrandomised, and the study groups were not comparable: the numbers recruited to the groups were not proportional to the months of recruitment, and there were differences between the groups in age, sex, and symptoms at enrolment, suggesting bias in the allocation of subjects to the study groups (table 2). For example, only $23 \%$ of the subjects in the subgroup of regular attenders to the clinic were controls, although about a third of the months were allocated for recruit-

\begin{tabular}{|c|c|c|c|c|c|c|}
\hline & Mandel et al $(1993)^{8}$ & Hardcastle et al (1996) ${ }^{9}$ & Kronborg et al $(1996)^{10}$ & Kewenter et al (1994) $)^{11}$ & Winawer et al $(1993)^{12}$ & Faive et al (1991) ${ }^{13}$ \\
\hline Study population & $\begin{array}{l}\text { Minnesota, USA, } \\
\text { volunteers aged 50-80 }\end{array}$ & $\begin{array}{l}\text { Nottingham, UK, subjects } \\
\text { aged } 45-74\end{array}$ & $\begin{array}{l}\text { Funen, Denmark, } \\
\text { inhabitants aged } 45-75\end{array}$ & $\begin{array}{l}\text { Gothenburg, Sweden, } \\
\text { inhabitants aged 60-64 }\end{array}$ & $\begin{array}{l}\text { New York, USA, clients } \\
\text { attending clinic aged } \\
\geqslant 40\end{array}$ & $\begin{array}{l}\text { Burgundy, France, } \\
\text { inhabitants aged } 45-74\end{array}$ \\
\hline $\begin{array}{l}\text { Study groups (No of } \\
\text { subjects allocated) }\end{array}$ & $\begin{array}{l}\text { Annual screen (15 570) } \\
\text { Biennial screen (15 587) } \\
\text { Control (15 394) }\end{array}$ & $\begin{array}{l}\text { Biennial screen (76 466) } \\
\text { Control (76 384) }\end{array}$ & $\begin{array}{l}\text { Biennial screen (30 967) } \\
\text { Control (30 966) }\end{array}$ & $\begin{array}{l}2 \text { screens, } 16-22 \text { months } \\
\text { apart, (34 144) } \\
\text { Control (34 164) }\end{array}$ & $\begin{array}{l}\text { Regular attenders }{ }^{*}: \\
\text { Annual screen (7168) } \\
\text { Control (2109) } \\
\text { First time attenders*: } \\
\text { Annual screen (5806) } \\
\text { Control (6673) }\end{array}$ & $\begin{array}{l}3 \text { screens planned, } 1-2 \\
\text { years apart, (45 500) } \\
\text { Control (45 500) }\end{array}$ \\
\hline \multicolumn{7}{|l|}{ Hemoccult screening: } \\
\hline Type of tests & $82.5 \%$ rehydrated & Unhydrated & Unhydrated & $\begin{array}{l}\text { Most rehydrated (all of } \\
\text { 2nd screen) }\end{array}$ & Most unhydrated & Unhydrated \\
\hline Screening periods & 1975-82 and 1986-92 & $\begin{array}{l}\text { Recruitment Feb } 1981 \text { to } \\
\text { Jan 1991, screening } \\
\text { ceased Feb } 1995\end{array}$ & $\begin{array}{l}\text { Aug } 1985 \text { to Aug 1995, } 5 \\
\text { screening rounds }\end{array}$ & $\begin{array}{l}\text { Started 1982, rescreening } \\
\text { offered } 16-22 \text { months } \\
\text { later }\end{array}$ & $\begin{array}{l}\text { Recruitment Mar } 1975 \text { to } \\
\text { Jul } 1979\end{array}$ & $\begin{array}{l}\text { 1st screen Jan-Jul } 1988 \\
\text { and Jan-Jul } 1989 \\
\text { 2nd screen Jan-Jul } 1990\end{array}$ \\
\hline Follow up & $\begin{array}{l}\text { Continuing at last report } \\
\text { in } 1993\end{array}$ & $\begin{array}{l}\text { To Jun } 1995 \text { (possibly } \\
\text { continuing) }\end{array}$ & Continues & Continues & Ceased Jul 1984 & Continues \\
\hline Completed screening & $\begin{array}{l}\text { Annual screen: } 90 \% \geqslant 1 \\
\text { screen, } 46 \% \text { all screens } \\
\text { Biennial screen: } 90 \% \geqslant 1 \\
\text { screen, } 60 \% \text { all screens }\end{array}$ & $\begin{array}{l}60 \% \geqslant 1 \text { screen, } 38 \% \text { all } \\
\text { screens }(3-6)\end{array}$ & $\begin{array}{l}67 \% 1 \text { st screen, } 46 \% \text { all } \\
5 \text { screens (rescreening } \\
\text { offered only to prior } \\
\text { attenders) }\end{array}$ & $\begin{array}{l}63 \% \text { 1st screen, } 60 \% \\
\text { 2nd screen, } 68 \% \geqslant 1 \\
\text { screen }\end{array}$ & $\begin{array}{l}\text { Regular attenders: } 70 \% \\
\text { 1st screen } \\
\text { First timers: } 80 \% \text { 1st } \\
\text { screen, } 20 \% \text { 2nd screen, } \\
16 \% \text { 3rd screen }\end{array}$ & $\begin{array}{l}54 \% \text { 1st screen, } 56 \% \\
\text { 2nd screen, } 64 \% \geqslant 1 \\
\text { screen }\end{array}$ \\
\hline Positivity rate & $\begin{array}{l}2.4 \% \text { unhydrated, } 9.8 \% \\
\text { rehydrated }\end{array}$ & $\begin{array}{l}2.1 \% \text { 1st screen, } 1.2 \% \\
\text { 2nd screen }\end{array}$ & $\begin{array}{l}1.0 \% \text { 1st screen, } 0.8 \% \\
\text { 2nd screen, } 0.9 \% \text { 3rd } \\
\text { screen, } 1.3 \% \text { 4th screen, } \\
1.8 \% 5 \text { th screen }\end{array}$ & $\begin{array}{l}\text { Unhydrated 1st screen: } \\
1.9 \% \text { 1st screen, } 8.0 \% \\
\text { 2nd screen } \\
\text { Rehydrated 1st screen: } \\
5.8 \% 1 \text { st screen, } 4.8 \% \\
\text { 2nd screen }\end{array}$ & $\begin{array}{l}1.4 \% \text { regular attenders } \\
2.6 \% \text { first timers }\end{array}$ & $2.3 \% 1$ st screen \\
\hline
\end{tabular}




\begin{tabular}{|c|c|c|c|c|c|c|}
\hline & $\begin{array}{l}\text { Mandel et al }(1993)^{8} \\
\text { Minnesota }\end{array}$ & $\begin{array}{l}\text { Hardcastle et al (1996) } \\
\text { Nottingham }\end{array}$ & $\begin{array}{l}\text { Kronborg et al (1996) } \\
\text { Funen }\end{array}$ & $\begin{array}{l}\text { Kewenter et al (1994) } \\
\text { Gothenburg }\end{array}$ & $\begin{array}{l}\text { Winawer et al }(1993)^{12} \\
\text { New York }\end{array}$ & $\begin{array}{l}\text { Faive et al }(1991)^{13} \\
\text { Burgundy }\end{array}$ \\
\hline $\begin{array}{l}\text { Allocation to screening } \\
\text { groups }\end{array}$ & $\begin{array}{l}\text { Individual random } \\
\text { allocation of volunteers. } \\
\text { Randomisation adequate }\end{array}$ & $\begin{array}{l}\text { Central randomisation of } \\
\text { households of subjects } \\
\text { identified from GP } \\
\text { records. Randomisation } \\
\text { adequate }\end{array}$ & $\begin{array}{l}\text { Individual random } \\
\text { allocation of subjects } \\
\text { identified from Central } \\
\text { Person Register. Couples } \\
\text { randomised together: } \\
\text { adequate }\end{array}$ & $\begin{array}{l}\text { Central randomisation of } \\
\text { all individuals in this age } \\
\text { group. Randomisation } \\
\text { adequate }\end{array}$ & $\begin{array}{l}\text { Non-random allocation } \\
\text { according to month of } \\
\text { attendance at clinic }\end{array}$ & $\begin{array}{l}\text { Non-random allocation of } \\
\text { groups from defined } \\
\text { geographical areas }\end{array}$ \\
\hline $\begin{array}{l}\text { Control for selection bias } \\
\text { after allocation to } \\
\text { screening }\end{array}$ & $\begin{array}{l}\text { Analysis by intention to } \\
\text { screen. No losses to } \\
\text { follow up or exclusions }\end{array}$ & $\begin{array}{l}\text { Analysis by intention to } \\
\text { screen. } 1.7 \% \text { of those } \\
\text { randomised lost to } \\
\text { follow up }\end{array}$ & $\begin{array}{l}\text { Analysis by intention to } \\
\text { screen. } 1145 \text { people } \\
(1.8 \%) \text { left Funen: all } \\
\text { followed up. }<6 \text { lost to } \\
\text { follow up (Kronborg, } \\
\text { personal communication) }\end{array}$ & $\begin{array}{l}197 \text { people from screen } \\
\text { group excluded after } \\
\text { randomisation. }<100 \\
\text { losses to follow up } \\
\text { subsequently }\end{array}$ & $\begin{array}{l}\text { Probable analysis by } \\
\text { intention to screen: not } \\
\text { clear about exclusions. } \\
\text { Vital status determined } \\
\text { for } 97 \% \text { by } 1984\end{array}$ & Not reported yet \\
\hline
\end{tabular}

$\mathrm{GP}=$ general practice. $\mathrm{CRC}=$ colorectal cancer.

ment of controls to this subgroup. In the nonrandomised Burgundy study all residents of certain towns and districts in the Saone et Loire department were invited to participate in screening. Controls were residents of areas of similar size from a neighbouring department. The selection process of towns and districts was not explained. Data about the comparability of the study groups are not yet available for the Burgundy study.

Mortality analyses were by intention to screen for the Minnesota, Nottingham, and Funen studies (table 2). In the Gothenburg trial 197 subjects were excluded from the screening group: these people could not be located or had died between randomisation and screening. ${ }^{16}$ It is not clear if there were exclusions in the New York study. Follow up was complete or high for all studies (table 2). Blinded standardised outcome assessment was performed for the four trials with published mortality findings (table 2 ).

\section{Intermediate outcome measures}

The estimated sensitivity of the Hemoccult test for colorectal cancer varied from $46 \%$ (unhydrated Hemoccult in the Funen trial) to $92 \%$ (rehydrated Hemoccult in the Minnesota trial) (table 3). Sensitivity was defined as the proportion of all colorectal cancers that were detected by screening, with all colorectal cancers being the sum of screen detected cancers (true positives) and interval cancers within one or two years of screening (false negatives) (table 3).

The percentage of people allocated to the screening group who completed at least one Hemoccult test ranged from $60 \%$ in the Nottingham trial to $90 \%$ in the Minnesota trial (table 1). Attendance for screening was higher in the American trials than in the European trials. Hemoccult screening continued to be offered to all participants in most trials, regardless of prior attendance (table 1).

Because screening results in earlier diagnosis of cancer, we would expect an excess of colorectal cancers initially in the screen groups. This was the case for four of the five trials in which these data were available (table 3). ${ }^{12}{ }^{16-18}$ It is unclear why this did not happen in the Min- nesota trial. ${ }^{19}$ It is possible that fewer cancers were detected in the screening group by chance, and this may then also be associated with an underestimation of mortality from colorectal cancer in the screening group.

In the screening groups, removal of adenomas detected at investigation of a positive Hemoccult test might affect later incidence of cancer. However, cumulative rates of colorectal cancer after 8-13 years of follow up were similar in screening and control groups in all of the trials (table 3).

Reported numbers of colorectal cancers varied at different points in the Minnesota paper. ${ }^{8}$ The paper's table 4 reported the numbers of cancers in the annual screening, biennial screening, and control groups as 323, 323, and 356 respectively, whereas the paper's table 5 and figure 3 reported these numbers as 354, 368 , and 394 respectively. The first set of numbers represent the numbers of colorectal cancers diagnosed through 13 years of follow up, as data were available for all study participants at 13 years; additional cancers diagnosed until 17 years of follow up were included for cancer staging and survival analyses (Mandel, personal communication).

We would also expect that screening would result in a favourable shift in the stage distribution of colorectal cancers. All five trials reported that, of the colorectal cancers detected, a higher proportion were early stage (Dukes's type A) and a lower proportion late stage (Dukes's type D or type C and D) in the screening groups than in the control groups (table 3). This favourable shift in cancer staging occurred even though only $25 \%-50 \%$ of cancers in the screening groups were actually detected by screening (table 3 ).

\section{Mortality}

Mortalities were published for the Minnesota, Nottingham, Funen, and New York trials (table 3). The Minnesota trial reported a $33 \%$ reduction in mortality from colorectal cancer with annual screening (relative risk $0.67(95 \%$ confidence interval 0.51 to 0.89$))$ and a $5 \%$ reduction with biennial screening (relative risk 0.95 $(0.74$ to 1.23$))$. The Nottingham and Funen studies reported reductions in mortality with biennial screen- 
Table 3 Results of trials of Hemoccult screening for colorectal cancer

\begin{tabular}{|c|c|c|c|c|c|}
\hline & $\begin{array}{l}\text { Mandel et al }(1993)^{8} \\
\text { Minnesota }\end{array}$ & $\begin{array}{l}\text { Hardcastle et al (1996) } \\
\text { Nottingham }\end{array}$ & $\begin{array}{l}\text { Kronborg et al }(1996)^{10} \\
\text { Funen }\end{array}$ & $\begin{array}{l}\text { Kewenter et al (1994) })^{11} \\
\text { Gothenburg }\end{array}$ & $\begin{array}{l}\text { Winawer et al }(1993)^{12} \\
\text { New York }\end{array}$ \\
\hline Years of trial follow up & 13 & Median 7.8 & 10 & Median 8.3 & 9 \\
\hline Early CRC: & & $\begin{array}{l}\text { At mean } 3 \text { year follow up } \\
\text { (107 } 349 \text { subjects) }\end{array}$ & At mean 3.2 year follow up & $\begin{array}{l}\text { At mean } 2.25 \text { year follow up } \\
\text { (27 } 700 \text { subjects) }\end{array}$ & At study entry \\
\hline No of cancers (rate/10 000) & $\begin{array}{l}\text { Initial screen approx } 87 \text { (28) } \\
\text { First year control approx } \\
45 \text { (29) }\end{array}$ & $\begin{array}{l}\text { Screen } 181(34) \\
\text { Control } 123(23)\end{array}$ & $\begin{array}{l}\text { Screen } 147(47) \\
\text { Control } 115(37)\end{array}$ & $\begin{array}{l}\text { Screen } 61 \text { (44) } \\
\text { Control } 20 \text { (14) }\end{array}$ & $\begin{array}{l}\text { Regular attenders: } \\
\text { Screen } 11(15) \\
\text { Control } 1(5) \\
\text { First time attenders: } \\
\text { Screen } 26(45) \\
\text { Control } 17(25)\end{array}$ \\
\hline Relative incidence $(95 \% \mathrm{Cl})$ & 0.96 (0.67 to 1.37$)$ & 1.47 (1.17 to 1.85$)$ & 1.28 (1.00 to 1.63$)$ & 3.03 (1.83 to 5.03 ) & 1.39 (0.79 to 2.44$)$ \\
\hline
\end{tabular}

\begin{tabular}{|c|c|c|c|c|c|}
\hline Relative incidence (95\% Cl) & 0.96 (0.67 to 1.37$)$ & $1.47(1.17$ to 1.85$)$ & 1.28 (1.00 to 1.63$)$ & 3.03 (1.83 to 5.03$)$ & 1.39 (0.79 to 2.44$)$ \\
\hline \multicolumn{6}{|l|}{ CRC at latest follow up: } \\
\hline No of cancers (rate/10 000) & $\begin{array}{l}\text { Annual screen } 323(207) \\
\text { Biennial screen } 323(207) \\
\text { Control } 356(231)\end{array}$ & $\begin{array}{l}\text { Screen } 893(117) \\
\text { Control } 856(112)\end{array}$ & $\begin{array}{l}\text { Screen } 481(155) \\
\text { Control } 483(156)\end{array}$ & $\begin{array}{l}\text { Screen } 371(108) \\
\text { Control } 379(111)\end{array}$ & $\begin{array}{l}\text { Regular attenders: } \\
\text { Screen } 72(100) \\
\text { Control } 22(104) \\
\text { First timers: } \\
\text { Screen } 57(98) \\
\text { Control } 48(72)\end{array}$ \\
\hline $\begin{array}{l}\text { Cancers detected by } \\
\text { Hemoccult screening }\end{array}$ & $\begin{array}{l}\text { Annual screen } 50 \% \\
\text { Biennial screen } 39 \%\end{array}$ & Screen $27 \%$ & Screen $25 \%$ & Screen $28 \%$ & All CRC 39\% \\
\hline $\begin{array}{l}\text { Sensitivity of Hemoccult for } \\
\text { colorectal cancer }\end{array}$ & $\begin{array}{l}\text { Rehydrated } 92 \% \\
\text { Unhydrated } 81 \% \\
\text { (Stated by authors) }\end{array}$ & $\begin{array}{l}\text { Unhydrated } 64 \% \\
\text { (Stated by authors) }\end{array}$ & Unhydrated $46 \%$ & $\begin{array}{l}\text { Overall (most rehydrated) } \\
81 \%\end{array}$ & Not calculable from data \\
\hline $\begin{array}{l}\text { Time after screening for interval } \\
\text { cancers to occur }\end{array}$ & 1 year & 2 years & 2 years & 2 years & - \\
\hline $\begin{array}{l}\text { No of CRC deaths at latest } \\
\text { follow up (rate/10 000) }\end{array}$ & $\begin{array}{l}\text { Annual screen } 82(53) \\
\text { Biennial screen } 117(75) \\
\text { Control } 121 \text { (79) }\end{array}$ & $\begin{array}{l}\text { Screen } 360(47) \\
\text { Control } 420(55)\end{array}$ & $\begin{array}{l}\text { Screen } 205(66) \\
\text { Control } 249(80)\end{array}$ & $\begin{array}{l}\text { Screen } 121(35) \\
\text { Control } 138(40)\end{array}$ & $\begin{array}{l}\text { Regular attenders: } \\
\text { Screen } 24(33) \\
\text { Control } 6 \text { (28) } \\
\text { First timers: } \\
\text { Screen } 12(21) \\
\text { Control } 22(33)\end{array}$ \\
\hline $\begin{array}{l}\text { Relative risk }(95 \% \mathrm{Cl}) \text { of } \mathrm{CRC} \\
\text { death with screening }\end{array}$ & $\begin{array}{l}\text { Annual screen } 0.67(0.51 \text { to } \\
0.89) \\
\text { Biennial screen } 0.95(0.74 \text { to } \\
1.23) \\
\text { Total } 0.81(0.65 \text { to } 1.02)\end{array}$ & $0.86(0.74$ to 0.99$)$ & $0.82(0.68$ to 0.99$)$ & $0.88(0.69$ to 1.12$)$ & $\begin{array}{l}\text { Regular attenders } 1.18 \\
(0.48 \text { to } 2.88) \\
\text { First timers } 0.63 \text { ( } 0.31 \text { to } \\
1.27) \\
\text { Total } 0.87 \text { ( } 0.53 \text { to } 1.43 \text { ) }\end{array}$ \\
\hline
\end{tabular}

$\mathrm{CRC}=$ Colorectal cancer .

ing of $14 \%$ (relative risk $0.86(0.74$ to 0.99$)$ ) and $18 \%$ (0.82 (0.68 to 0.99$))$ respectively. Results from the New York study were reported for two subgroups defined by whether the subjects had attended the clinic previously (regular attenders) or were attending for the first time. After nine years of follow up, there was a $37 \%$ reduction in mortality with annual screening among those attending for the first time (relative risk $0.63(0.31$ to 1.27$)$ ) but an $18 \%$ increase in mortality with annual screening among the regular attenders (relative risk 1.18 (0.48 to 2.88$))$.

The Gothenburg and Burgundy trials have still to publish mortality findings. Unpublished results from the Gothenburg trial indicate that, after eight years of follow up, there was a $12 \%$ reduction in mortality with biennial screening (relative risk 0.88 (0.69 to 1.12)) (table 3).

Adverse events relating to colonoscopy or sigmoidoscopy were reported for only the Minnesota and Gothenburg trials. In the Minnesota trial four perforations and 11 cases of serious bleeding resulted from 12246 colonoscopies (12 complications per 10000 colonoscopies). The Gothenburg trialists reported that $0.3 \%$ of 2298 endoscopies (colonoscopies and sigmoidoscopies) were complicated by perforation or haemorrhage (30 complications per 10000 endoscopies).
Meta-analysis

The Minnesota trial found a 33\% reduction in mortality from colorectal cancer with annual screening and a 5\% reduction with biennial screening. We combined these risks of death for the two screening groups for reasons discussed later, and comparison of this value with the risk in the control group suggests an overall reduction of $19 \%$ in the risk of death with screening (relative risk 0.81 (0.65 to 1.02)) (table 3).

The mortality results from the four randomised controlled trials did not seem to be heterogeneous, and formal testing for heterogeneity confirmed this $\left(\chi^{2}\right.$ test for heterogeneity $0.37, \mathrm{df}=4, \mathrm{P}>0.5)$. We combined the mortality results from these four trials to obtain a summary measure of the effectiveness of screening for colorectal cancer with Hemoccult (figure). Metaanalysis with a random effects model showed that screening resulted in a significant overall reduction in mortality from colorectal cancer of $16 \%$ (relative risk $0.84(0.77$ to 0.93$))$. With a fixed effects model, the summary relative risk was unchanged, and the 95\% confidence interval decreased by 0.01 . When we adjusted the relative risk for attendance for screening in individual studies (using the data from table 3 on the percentage who completed at least one screen) the 


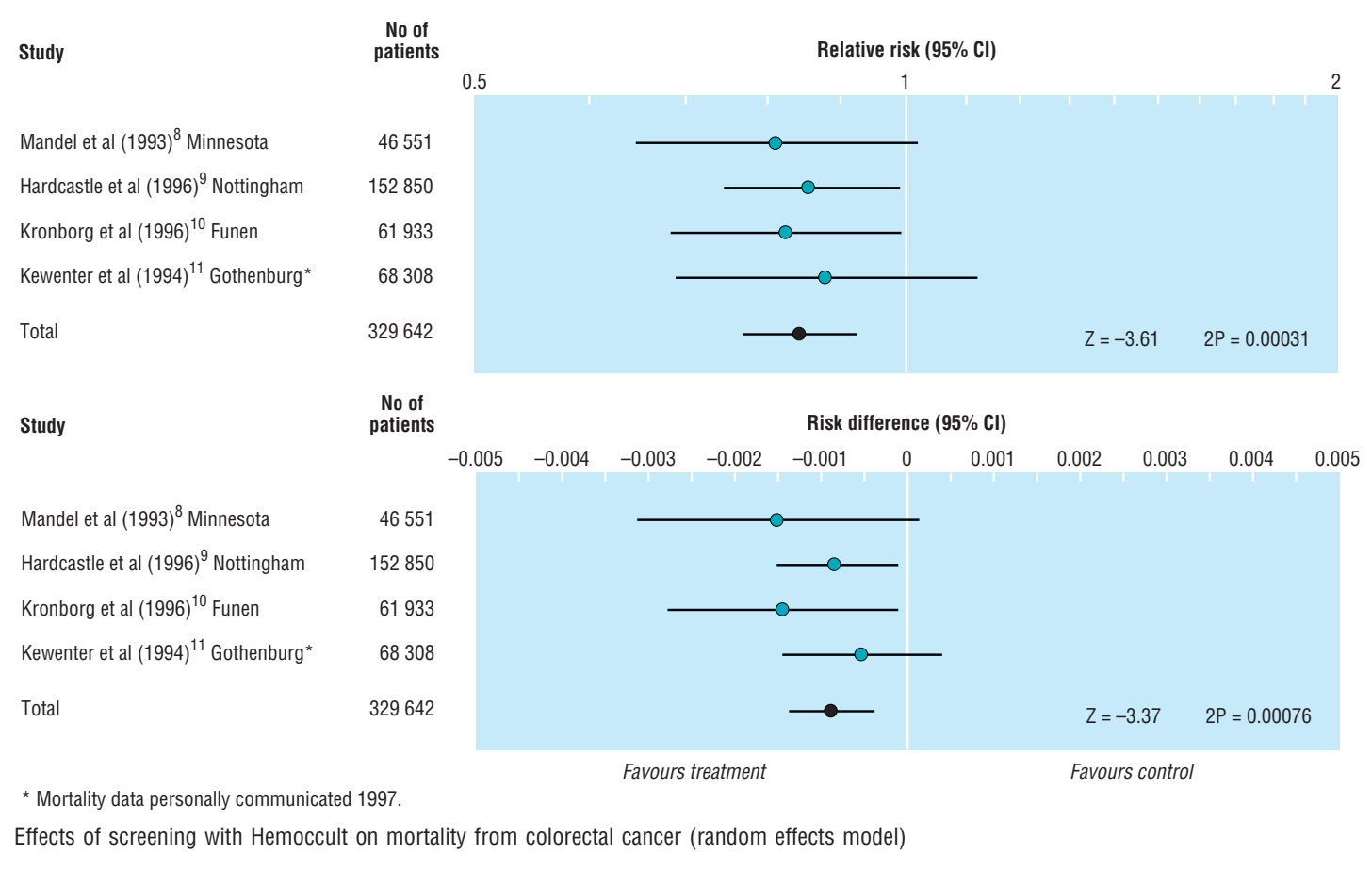

overall relative reduction in mortality was $23 \%$ (relative risk 0.77 (0.57 to 0.89$))$ for those screened.

Including the results from the non-randomised New York study in the meta-analysis made no substantive difference to the summary result (relative risk 0.84 ( 0.77 to 0.92)) with both fixed or random effects models.

The meta-analysis shows more variability in the risk difference than in the relative risk (figure). As the relative risk was relatively constant, the variability in the risk difference is a reflection of the variation in the background risk of death from colorectal cancer in the various study populations-ranging from 40 deaths per 10000 population in the Gothenburg study to 80 deaths per 10000 in the Funen study. Overall, if 10000 people were offered screening, 8.5 (95\% confidence interval 3.6 to 13.5) deaths from colorectal cancer would be prevented over 10 years. To state this another way, the number needed to screen in order to prevent one death from colorectal cancer over 10 years is 1173 (741 to 2807) with either fixed or random effects models.

\section{Discussion}

The combined evidence to date from randomised controlled trials of Hemoccult screening suggests that screening reduces mortality from colorectal cancer. The point estimate is $16 \%$, but the reduction may be as great as $23 \%$ or as little as $7 \%$. Mortality results are not yet published for the Gothenburg and Burgundy trials, although results from Gothenburg have been included in this meta-analysis and the Burgundy study is not randomised. The reduction in mortality associated with screening was consistent across the five trials with mortality results even though they varied in the selection and age of their study populations, screening intervals, conditions of Hemoccult testing and slide processing, length of follow up, and attendance for screening.

The results of the Minnesota trial seem paradoxical: a 33\% reduction in mortality from colorectal cancer with annual screening, but a $5 \%$ reduction with biennial screening. Screening twice as often can, at best, double the relative reduction in mortality, but the effect is usually much less. If the benefit of annual screening was more than double that of biennial screening, it would suggest that screening half the population every year would have a greater impact than screening all the population every two years. To consider this another way, even if the sojourn time of cancers is less than a year, a screen every two years must pick up the cancers that arose in the past year (and hence would be picked up by annual screening). So the effect of biennial screening must be at least half that of annual screening, and will be more than half to the extent that the distribution of sojourn times exceeds a year. Thus, we believe that the difference in mortality reduction between the annual and biennial screen groups in the Minnesota trial is partly due to the play of chance. This play of chance may have occurred at randomisation, since the screening groups did not show the expected higher initial rate of colorectal cancers as a result of screening.

\section{Implications of results}

Who would be likely to benefit from screening? Assuming a constant reduction in relative risk, the benefit of screening is greatest in populations at greatest risk of death from colorectal cancer while the harmful effects of screening are likely to be independent of this risk. ${ }^{20}$ Indeed, the screening trials showed increasing benefit of screening with increasing population risk of death from colorectal cancer. The reduction in the relative risk of death with screening needs to be interpreted for its benefit in the overall population, in which there are differing baseline risks of colorectal cancer. In addition to people from families with a known genetic predisposition for colorectal cancer (including familial adenomatous polyposis and hereditary non-polyposis colorectal cancer) groups at increased risk of colorectal 
- We conducted a systematic review of trials of screening for colorectal cancer with faecal occult blood test, Hemoccult

- Meta-analysis of results from the four randomised controlled trials showed that screening reduced mortality from colorectal cancer by $16 \%$ for those allocated to screening and by $23 \%$ for those who were actually screened

- A biennial Hemoccult screening programme offered to 10000 people aged $\geqslant 40$ years, of whom about two thirds attended for at least one test, would prevent 8.5 deaths from colorectal cancer over 10 years

- Although benefits of screening are likely to outweigh harms for populations at high risk of colorectal cancer, we need more information about the harmful effects of screening, the community's responses to screening, and costs of screening for different healthcare systems before widespread screening can be recommended

cancer (and thus death from cancer) include those with a family history of colorectal cancer of no known genetic basis. ${ }^{21-24}$ The risk of colorectal cancer also increases markedly with age. ${ }^{1}$

The expected benefit of screening can be estimated for different populations to guide health policy decisions about who should be offered screening. For example, in New South Wales, Australia, in 1991 the cumulative 10 year mortality from colorectal cancer in men in their $40 \mathrm{~s}, 50 \mathrm{~s}$, and $60 \mathrm{~s}$ were $9.6,40$, and 98 respectively per 10000 population. ${ }^{1}$ If offering screening reduced this mortality by $16 \%$ the reduction in deaths over the following 10 years for each of these age groups would be $1.5,6.4$, and 15.6 respectively per 10000 invited. This somewhat overestimates the benefit, as some of the mortality relates to cancers diagnosed before that decade. However, it is also an underestimate for those who actually attend for screening. If we use the mortality reduction of 23\% estimated for those actually screened, the reduction in deaths over 10 years would be 2.2, 9.2, and 22.5 respectively per 10000 .

Based on the combined results of the four randomised controlled trials of Hemoccult screening, we estimate that, if a biennial screening programme were offered to 10000 people, of whom about two thirds attended for at least one Hemoccult test, 8.5 colorectal cancer deaths would be prevented over about 10 years. The number of colonoscopies or sigmoidoscopies performed among the screening groups to achieve this reduction in mortality could range from 20 to 800 per life prolonged, according to the results of the screening trials. If we consider the harm of screening, the results from the Minnesota trial indicate that a biennial screening programme would result in 2800 participants having at least one colonoscopy, with there being 3.4 complications (perforation or haemorrhage) associated with these colonoscopies. The results from the Gothenburg trial, however, indicate that about 600 participants would need at least one sigmoidoscopy and double contrast barium enema, resulting in 1.8 perforations or haemorrhages. Colonoscopy rates were lower for the trials in which the Hemoccult stool slides were not rehydrated, but information about complications was not reported.

An important issue is the accuracy of the screening test. Under trial conditions, which are likely to be supe- rior to those of a screening programme, Hemoccult had a low positive predictive value for cancer, so that over $80 \%$ of positive tests were false (table 3 ). All these people still required investigation, with its associated stress and risk of bowel perforation and haemorrhage. Since the trials were initiated, other faecal occult blood tests have emerged that may be more accurate. ${ }^{25} 26$ More specific tests will potentially have a major impact on the ratio of benefit to harm of a screening programme, as fewer false positive tests will mean fewer colonoscopies, with their associated harms, for the same benefit in terms of reduced mortality from colorectal cancer. It is also worth noting that among the people with a false positive test for cancer are some with colorectal adenomas. Further analysis of trial data during follow up should clarify whether the detection and removal of adenomas alters the subsequent incidence of cancer, and thus mortality.

\section{Conclusions}

The estimate of the reduction in mortality associated with screening for colorectal cancer with Hemoccult is now well quantified, and the confidence intervals are narrow enough to allow the conclusion that screening is likely to be of net benefit for some population groups. Other benefits of screening that we have not explored include a possible reduction in incidence of colorectal cancer through detection and removal of colorectal adenomas and, potentially, less invasive surgery through treatment of early colorectal cancers.

However, there are still some important issues to be answered. There is insufficient information from the trials about the harmful physical and psychosocial effects of screening. What does the community think and feel about screening? How do we best inform high risk populations about the pros and cons of screening, and would these people participate in screening? Can the necessary quality of screening and follow up be achieved outside trials, and would expenditure on screening constitute a sound use of resources given local priorities in health care? These questions require further evaluation by researchers for different healthcare systems.

We thank Jack Hardcastle, Ole Kronborg, and Jack Mandel for reading and commenting on drafts of this review. We thank Joseph Lau for providing Meta-analyst version 0.991 and changing it to accommodate the sample size in the trials. We thank Philippa Middleton for help with literature searching.

Contributors: BT coordinated the project and participated in project conception, literature searching, study retrieval and appraisal, data extraction, data analysis and interpretation, writing the paper, and editing drafts. LI initiated the project and participated in project conception, study retrieval, data extraction, data analysis and interpretation, writing the paper, and editing drafts. PG participated in project conception, literature searching, study appraisal, data analysis and interpretation, writing the paper, and editing drafts. JK participated in project conception, provided substantial unpublished data to the metaanalysis, and assisted with editing drafts. DW participated in project conception and assisted with interpretation of results and editing drafts. CS participated in project conception and assisted with interpretation of results and editing drafts. BT, LI, and $\mathrm{PG}$ are guarantors for the paper.

Funding: None.

Conflict of interest: None.

1 Jeffs P, Coates M, Giles G, Shugg D, Threlfall T, Roder D, et al. Cancer in Australia 1989-1990 (with projections to 1995). Canberra: Australian Institute of Health and Welfare, 1996. (Cancer Series No 5.) 
2 Parkin DM, Muir CS, Whelan SL, Gao YT, Ferlay J, Powell J, eds. Cancer incidence in five continents. Vol VI. Lyon: International Agency for Research on Cancer, International Association of Cancer Registries, 1992.

3 Stewart Brown S, Farmer A. Screening could seriously damage your health. Decisions to screen must take account of the social and psychological costs. BMJ 1997;314:533-4.

4 Mulrow CD, Oxman AD, eds. Critical appraisal of studies. Cochrane Collaboration handbook [updated 9 December 1996]. Section 6. In: The Cochrane Library [database on disc and CD ROM]. Cochrane Collaboration; Issue 1. Oxford: Update Software; 1997. Updated quarterly.

5 Lau J. Meta-analyst version 0.991. A program for the meta-analysis of 2 by 2 tables. Boston MA: New England Medical Center, 1997.

6 Petitti DB. Meta-analysis, decision analysis and cost-effectiveness analysis:methods for quantitative synthesis in medicine. Oxford: Oxford University Press, 1994.

7 Glasziou PP. Meta-analysis adjusting for compliance: the example of screening for breast cancer. J Clin Epidemiol 1992;45:1251-6.

Mandel JS, Bond JH, Church TR, Snover DC, Bradley GM, Schuman LM, et al. Reducing mortality from colorectal cancer by screening for fecal occult blood. N Engl J Med 1993;328:1365-71.

9 Hardcastle JD, Chamberlain JO, Robinson MHE, Moss SM, Amar SS, Balfour TW, et al. Randomised controlled trial of faecal-occult-blood screening for colorectal cancer. Lancet 1996:348:1472-7.

10 Kronborg O, Fenger C, Olsen J, Jorgensen OD, Sondergaard O. Randomised study of screening for colorectal cancer with faecal-occultblood test. Lancet 1996;348:1467-71

11 Kewenter J, Brevinge H, Engaras B, Haglind E, Ahren C. Results of screening, rescreening, and follow-up in a prospective randomized study for detection of colorectal cancer by fecal occult blood testing. Results for 68,308 subjects. Scand J Gastroenterol 1994;29:468-73.

12 Winawer SJ, Flehinger BJ, Schottenfeld D, Miller DG. Screening for colorectal cancer with fecal occult blood testing and sigmoidoscopy. J Natl Cancer Inst 1993;85:1311-8.

13 Faive J, Arveux P, Milan C, Durand G, Lamour J, Bedenne L. Participation in mass screening for colorectal cancer: results of screening and rescreening from the Burgundy study. Eur J Cancer Prev 1991;1:49-55.

14 Kewenter J, Brevinge $\mathrm{H}$. Endoscopic and surgical complications of work-up in screening for colorectal cancer. Dis Colon Rectum 1996; $39 \cdot 676-80$.
15 Gilbertson VA, Church TR, Grewe FJ, Mandel JS, McHugh RB, Schuman $\mathrm{LM}$, et al. The design of a study to assess occult-blood screening for colon cancer. J Chron Dis 1980;33:107-14.

16 Kewenter J, Bjork S, Haglind E, Smith L, Svanvik J, Ahren C. Screening and rescreening for colorectal cancer. A controlled trial of fecal occult blood testing in 27700 subjects. Cancer 1988;62:645-51.

17 Hardcastle JD, Thomas WM, Chamberlain J, Pye G, Sheffield J, James PD, et al. Randomised, controlled trial of faecal occult blood screening for colorectal cancer. Results for first 107349 subjects. Lancet 1989;i:1160-4.

18 Kronborg O, Fenger C, Olsen J, Bech K, Sondergaard O. Repeated screening for colorectal cancer with fecal occult blood test. A prospective randomized study at Funen, Denmark. Scand J Gastroenterol 1989;24:599 606.

19 Church TR, Mandel JS, Bond JH, Ederer F, Snover DC, Bradley GM, et al. Colon cancer control study: status and current issues. In: Miller $\mathrm{AB}$ Chamberlain J, Day NE, Hakama M, Prorok PD, eds. Cancer screening. Cambridge: Cambridge University Press, 1991:83-105.

20 Glasziou PP, Irwig LM. An evidence based approach to individualising treatment. BMJ 1995;311:1356-9.

21 Guidelines for early detection, screening and surveillance for colorectal cancer. 2nd ed. Sydney: Australian Gastroenterology Institute, Australian Cancer Society, 1994.

22 Lynch HT, Rozen P, Shuelke GS. Hereditary colon cancer: polyposis and non-polyposis variants. Cancer 1985;35:95-115.

23 Dunlop MG. Screening for large bowel cancer in individuals with a family history of colorectal cancer. BrJ Surg 1992;79:488-94.

24 St John DJ, McDermott FT, Hopper JL, Debney EA, Johnson WR, Hughes ESR. Cancer risk in relatives with common colorectal cancer. Ann Intern Med 1993;118:785-90.

25 Castiglione G, Zappa M, Grazzini G, Mazzotta A, Biagini M, Salvadori P, et al. Immunochemical versus guaiac faecal occult blood tests in a population based screening program for colorectal cancer. Br J Cancer 1996 74:141-4.

26 Allison JE, Tekawa IS, Ransom LJ, Adrain AL. A comparison of faecal occult blood tests for colorectal cancer screening. N Engl J Med 1996; 334:155-9.

(Accepted 13 May 1998)

\title{
Changes in left ventricular structure and function in patients with white coat hypertension: cross sectional survey
}

\author{
Michael W Muscholl, Hans-W Hense, Ulrich Bröckel, Angela Döring, Günter A J Riegger,
} Heribert Schunkert

\begin{abstract}
Objectives: To assess the relation between white coat hypertension and alterations of left ventricular structure and function.

Design: Cross sectional survey.

Setting: Augsburg, Germany.

Subjects: 1677 subjects, aged 25 to 74 years, who participated in an echocardiographic substudy of the monitoring of trends and determinants in cardiovascular disease Augsburg study during 1994-5. Outcome measures: Blood pressure measurements and $\mathrm{M}$ mode, two dimensional, and Doppler echocardiography. After at least 30 minutes' rest blood pressure was measured three times by a technician, and once by a physician after echocardiography. Subjects were classified as normotensive (technician $<140 / 90 \mathrm{~mm} \mathrm{Hg}$, physician <160/95 mm Hg; $\mathrm{n}=849$ ), white coat hypertensive (technician < 140/90 $\mathrm{mm} \mathrm{Hg}$, physician $\geqslant 160 / 95 \mathrm{~mm} \mathrm{Hg} ; \mathrm{n}=160$ ), mildly hypertensive (technician $\geqslant 140 / 90 \mathrm{~mm} \mathrm{Hg}$, physician $<160 / 95 \mathrm{~mm} \mathrm{Hg} ; \mathrm{n}=129$ ), and sustained hypertensive (taking antihypertensive drugs or blood pressure measured by a technican $\geqslant 140 / 90 \mathrm{~mm} \mathrm{Hg}$, and physician $\geqslant 160 / 95 \mathrm{~mm} \mathrm{Hg} ; \mathrm{n}=538$ ).

Results: White coat hypertension was more common in men than women (10.9\% versus $8.2 \%$ respectively) and positively related to age and body mass index.
\end{abstract}

After adjustment for these variables, white coat hypertension was associated with an increase in left ventricular mass and an increased prevalence of left ventricular hypertrophy (odds ratio 1.9, 95\% confidence interval 1.2 to $3.2 ; \mathrm{P}=0.009$ ) compared with normotensive patients. The increase in left ventricular mass was secondary to significantly increased septal and posterior wall thicknesses whereas end diastolic diameters were similar in both groups with white coat hypertension or normotension. Additionally, the systolic white coat effect (difference between blood pressures recorded by a technician and physician) was associated with increased left ventricular mass and increased prevalence of left ventricular hypertrophy $(\mathrm{P}<0.05$ each). Values for systolic left ventricular function (M mode fractional shortening) were above normal in subjects with white coat hypertension whereas diastolic filling and left atrial size were similar to those in normotension.

Conclusion: About 10\% of the general population show exaggerated inotropic and blood pressure responses when mildly stressed. This is associated with an increased risk of left ventricular hypertrophy.

\section{Introduction}

A physical examination by a physician may cause a rise in the patient's blood pressure. Individuals showing
Klinik und

Poliklinik für Innere

Medizin II,

University of

Regensburg,

D-93042

Regensburg,

Germany

Michael W

Muscholl,

clinical fellow in

cardiology

Ulrich Bröckel,

clinical fellow in

cardiology

Günter A J Riegger,

professor of internal

medicine

Heribert Schunkert assistant professor

Institut für

Epidemiologie und

Sozialmedizin,

University of

Münster, Münster,

Germany

Hans-W Hense,

professor of clinical

epidemiology

continued over

BMJ 1998;317:565-70 